DOI: https://doi.org/10.32838/2523-4803/69-5-57

УДК 338.24

\title{
Бодрова Д.В.
}

магістр,

Київський національний університет імені Тараса Шевченка

\section{Bodrova Dariia}

Kyiv National Taras Shevchenko University

\section{ІНСТИТУЦІОНАЛЬНІ АСПЕКТИ РОЗВИТКУ ЦИФРОВОЇ ЕКОНОМІКИ В УКРАЇНІ}

У статті розглядаються актуальні проблеми, суперечності становлення та розвитку изифрової економіки в Україні, досліджуються особливості і шляхи їх вирішення у процесі інституціональноструктурної трансформачії економічної системи. Метою статті є переосмислення зазначених процеесів ццифровізації економіки і капіталу з огляду на породжувані ними проблеми, виклики, можливості та особливості реалізації в контексті формування та інституціоналізації інформаційного суспільства в Україні. Проаналізовано інституціональні аспекти реалізації Концепції розвитку цифрової економіки та суспільства Украӥни на 2018-2020 роки, розкрита роль та основні функиї державного регулювання ицирровізаиії економіки емерджентного типу, зокрема, створення інституціональної інфраструктури діджиталізації економіки і суспільства, перехід від електронного до цифрового врядування. стимулювання цицровізації виробничих процесів, інформаційна, ичифрова безпека та подолання ичифрової нерівності.

Ключові слова: інтернет, інституціональні трансформації, інформаційне суспільство, інформаиійні технології, ІТ-індустрія, ичифровізація, циифрове врядування. ичифрова економіка.

Постановка проблеми. Одним 3 визначальних векторів розвитку сучасних економічних систем як на рівні національних, так і світового господарств, все відчутніше виступає цифровізація соціогосподарських явищ і процесів на новій технологічній основі. Цифрова економіка, в якій кіберфізична система забезпечує 
взаємодію віртуальної і реальної частин виробничих процесів, проявляється не тільки в якості виробника товарів або послуг, але і в становленні життєустрою на якісно новому технологічному рівні. Саме цифровізація (діджиталізація) економіки розглядається сьогодні як модель і стратегія сучасного світового інноваційного розвитку, в т.ч. і для країн з емерджентною економікою, що стали на шлях перебудови своїх господарських систем з метою підвищення їх ефективності i скорочення розриву з розвинутими країнами. Тому феномен цифрової економіки потребує детального дослідження з огляду на специфіку іiі становлення та інституціонального розвитку в Україні.

Аналіз останніх досліджень і публікацій. На думку багатьох відомих дослідників проблем і чинників економічного зростання,зокрема, Д. Белла [1], Е. Денісона [2], М. Кастельса [3], Ф. Махлупа [4], П. Друкера [5] та інших вже, починаючи 3 другої половини 20 ст. інформація стає основним ресурсом, фактором, предметом і продуктом виробництва найрозвинутіших країн. Протягом останнього десятиріччя промисловий капітал втрачає свої позиції і йому на зміну приходить цифровий капітал. Три найбільш капіталізовані компанії в світі на початок вересня 2018 року належать до технологічного сектору (Apple, Amazon, Google). Їх акції сукупно оцінюються в більш ніж 2,8 трлн. дол. США, а це в 25 рази перевищує ВВП України за 2017 рік [6, с. 63]. Десять років тому вони навіть не могли потрапити в ТОП-30 найдорожчих компаній світу, де домінували фінансові конгломерати (HSBC Holdings, Bank of America, JPMorgan Chase) i широко відомі промислові корпорації (General Electric, ExxonMobil, Royal Dutch Shell, BP, Toyota Motor i iн.).

Вибухова революція в інформаційних технологіях поряд 3 незапереч-ними перевагами, новою якістю економічної системи висуває низку проблем і викликів перед сучасною економічною наукою і господарською практикою. На думку британського науковця Дж.Веста, «.мова тут йде не тільки про збір і громадження даних, але й про аналіз і перетворення величезних обсягів знову і знову виникаючої інформації у придатну для обробки форму, яка дозволяє робити спостереження, помічати закономірності або формулювати й перевіряти передбачення» [7, с. 489].

Мета статті полягає в переосмисленні зазначених процесів цифровізації економіки і капіталу з огляду на породжувані ними проблеми, виклики, можливості та особливості реалізації в контексті формування та інституціоналізації інформаційного суспільства в Україні.

Виклад основного матеріалу. У провідних країнах світу щорічний обсяг інвестицій в цифровізацію економіки вже налічує близько одного три-льйона доларів на рік. До 2020 року економіки країн-лідерів витратять на цифровізацію майже 15 трл. дол. США. Так, наприклад, у Німеччині цифровізація промисловості визначена у 2013 р. Програмою переходу до цифрової економіки[8, с. 48]. Головною іiї метою є створення виробництв винятково на цифровій основі для подолання можливих економічних криз 21 ст. Один $з$ лідерів європейської економіки, їі «локомотивів» здійснює процес діджиталізації як виробництва, так і невиробничої сфери, зокрема, повністю роботизовані: виробнича лінія заводу Porsche, склади інтернет-торгівлі компанії Amazon, безпілотний міні-автобус, екзоскелети, перчатки ProGlove, інтернет-банкінг і т.п.

У США вже зараз діють більше 9 тис. повністю автоматизованих виробництв, а на 10 тис. робочих місць у виробництві припадає 870 промислових роботів, у Японії - 400, в Південній Кореї - 270, в Китаї - 32. В Україні цей же показник не перевищує i 3 [9, с. 272]. За даними Свропейської Комісії цифрова економіка оцінюється у 2,3 трлн. євро в групі країн «Великої двадцятки» і складає близько 8\% ВВП. Інтернет сьогодні - один з найважливіших елементів економічного прогресу, він інституціонально забезпечує значну частину зростання економіки: внесок інтернету у ВВП розвинутих країн за 15-річний період 1995-2009 рр. сумарно склав 10\%, причому за останні 6 років (2011-2017) він зріс більш, ніж у два рази - до $21 \%[10]$. Частка цифрової економіки у ВВП України у 2018 р. становила 4\% ВВП, що у 2-3 рази нижче американського, европейського й китайського показників [11]. Разом $з$ тим, темпи збі-льшення частки цифрової економіки значно випереджають темпи зростання ВВП, тому розгортання вітчизняної ІТ-індустрії розглядається ке-рівництвом держави в якості одного 3 основних драйверів зростання. Наприкінці 2017 р. Мінекономрозвитку презентувало «Цифрову адженду України - 2020», яка містить концептуальні засади, першочергові сфери, ініціативи, проекти «цифровізації» України до 2020 року. Цей документ став основою для схваленої Кабміном України «Концепції розвитку цифрової економіки та суспільства України на 2018-2020 роки» від 17.01.2018 № 67-р та затвердження плану заходів щодо іiї реалізації [12]. Концепція передбачає здійснення заходів щодо впровадження відповідних стимулів для цифровізації економіки, суспільної та соціальної сфер, усвідомлення наявних викликів та інструментів розвитку цифрових інфраструктур, набуття громадянами цифрових компетенцій, а також визначає критичні сфери та проекти цифровізації, стимулювання внутрішнього ринку виробництва, використання та споживання цифрових технологій. Важливим складником цифрової трансформації економіки України є цифровізація освітніх процесів та набуття цифрових компетенцій громадянами на шляху до поглиблення європейської інтеграції. «Цифрові рішення - це пріоритет розвитку... В Україні у сфері IT та у стартапах працює 150 тисяч осіб. Ми розвиватимемося у цьому напрямі», - заявив Президент України В.О. Зеленський. На сьогодні Україна увійшла у топ 40 країн світу за кількістю стартапів і посіла 31 місце [11].

Світовими трендами діджиталізації національних економічних систем виступають, у першу чергу, роз- 
виток технологій створення мікроелектроме-ханічних систем (MEMS), когнітивної робототехніки, систем автоматизова-ного проектування (САПР), мехатроніки, високоточних приладів, надчутли-вих сенсорів, попередньої обробки сигналів, хмарних даних, інтернет-засобів і т.п. Це саме ті технології, які забезпечують матеріалізацію цифровізації виробничих процесів. Модернізацію промислового сектора економіки України також передбачається проводити на базі цифровізації основних систем і виробничих комплексів, створення віртуального середовища конкурентоспроможних товарів / послуг з їх подальшою матеріалізацією в «оцифрованому» виробництві. Ефективність такого підходу полягає в мінімізації управлінських витрат за рахунок освоєння «віртуального» етапу відпрацювання технологічних процесів виробництва. Однак сьогодні вітчизняна промисловість змушена застосовувати переважно старі, ще радянські, виробничі технології, далекі від прецизійності, які здатні створювати на наявному обладнанні деталі з точністю до 0,1 мм. У той же час в Німеччині, США та Японії на базі ци-фрових технологій вже виробляють обладнання для обробки деталей з точністю 0,0001 мм, і навіть 0,000001 мм. Більш того, всі необхідні компетенції в області MEMS були досягнуті, наприклад, Німеччиною ще до 2012 р.[8, с. 49].

Наведені приклади дозволяють зробити висновок про те, що реалізація зазначеної Концепції з подальшим розвитком іiї основних положень у стратегічних рішеннях 3 діджиталізації українського суспільства практично неможлива без спеціального технологічного обладнання, що забезпечує створення мікромашино- i приладобудування, наноелектроніки та нанофотоніки поза цифрової основи. Тому перш ніж «мріяти» про перехід до цифрової економіки як такої, необхідно спочатку забезпечити вітчизняні підприємства високотехнологічним обробним устаткуванням такого рівня, на якому можна було б створювати деталі розміром до 1 мікрона (0,001 мм). В цьому плані,насамперед, необхідно організаційно відтворити, крім відповідних освітянських і наукових струтктур, промислові структури, які зможуть забезпечити розвиток технологій (методів і засобів) типу MEMS. Зробити це можливо навіть в умовах практично перманентної світової економічної кризи.

Широкомасштабне виробництво вітчизняних чіпів в країні так і не на-лагоджено, тим більше що конкурувати зараз в цій сфері, наприклад, з Китаєм, мабуть, навряд чи можливо. Проте, проголошений українською владою курс на цифровізацію економіки, «державу у смартфоні» може призвести в разі успішного розвитку подій до істотного переформатування, автоматизації та роботизації виробництва, створення наукомістких технологічних підприємств і висококваліфікованих робочих місць.

Концепція розвитку цифрової економіки та суспільства України на 2018-2020 роки і передбачувані нею заходи і складний процес їх реалізації поклали початок, насамперед, інтенсивного використання органами держав-ної влади та громадянами інформаційних і комунікаційних технологій, які намагаються впроваджувати як в традиційні, так і в народжувані нові галузі і сфери вітчизняної економіки. Слід віддати належне: повсюдно починають застосовуватися технології збору та обробки даних, обміну ними, навіть в побуті. Управління виробничими процесами на цифровій основі також має забезпечити потужний мультиплікативний ефект для розвитку всього національного господарства. Проте, важлива роль цифровізації як способу модернізації української економіки не виключає її основні проблеми:

1. Недооцінка соціального та інших вимірів розвитку сучасної економіки, наприклад, неоднорідності розвитку українських регіонів. Швидше за все, цифровізація стане стратифікованою, а не однорідною.

2. Зниження продуктивності у сфері виробництва самих цифрових технологій i, в свою чергу, уповільнення інвестування в їх розвиток.

3. Зниження кваліфікації виробничого персоналу в умовах його перетворення у придаток оцифрованих виробництв, витіснення праці не тільки низької, а й середньої кваліфікації.

4. Зростання імовірності технологічних збоїв і техногенних катастроф, інформаційно-цифрових маніпуляцій і шахрайських операцій у невиробничій сфері.

5. Уповільнення зростання частки цифрової економіки у ВВП, що вже спостерігається в низці промислово розвинених країн.

6.Витіснення базових технологічних процесів, науково-технічних інновацій, а також економічних відносин, пов'язаних з соціальною орієнтацією економіки України.

7. Обмежені можливості урахування специфіки української економіки, співвідношення державного регулювання і ринку.

8. Загрози економічній безпеці країни, насамперед, іiї кібер- і військово-промисловій безпеці.

9. Вихід вітчизняних ІТ-компаній з-під державного контролю, оподаткування тощо.

10. Загострення соціальних суперечностей при масовому вивільненні працівників, зниження ступеня соціальної захищеності внаслідок розширення автономності учасників мережевої цифрової економіки, посилення соціальної нерівності, в т. ч. і внаслідок наявної цифрової нерівності, перетворення соціальноекономічних суб'єктів у «гвинтики» технологічного прогресу.

Таким чином, спостерігається реальна небезпека абсолютизації і фетишизації процесу цифрової трансформації незміцнілої після економічних криз і політичних потрясінь, емерджентної економіки України. Найголовніша ж проблема полягає в тому, що відбувається цілеспрямоване перетворення людини-творця в кваліфікованого ринкового споживача, який вміло застосовує інформаційні технології. Частково демпфірувати проблеми цифровізації економіки в умовах гло- 
балізації дозволяє іiї регулювання з боку держави та іiі відповідних інституцій. При цьому, на думку відомого польського економіста Г. Колодко, загалом, все має зводитись до питання про способи, механізми регулювання: не керувати, не врядувати, а саме спрямовувати господарських процеси, щоб результати економічної діяльності слугували як можна більш широкому колу людей. Обробка широкого пласту інформації можлива лише при її цифровізації [13, с. 173-175].

В даному контексті виникає природне запитання: чи можлива в прин-ципі обробка того обсягу інформації, який передбачається продукувати в структурах, покликаних регулювати створювану українську цифрову еконо-міку? На це питання намагалися відповісти ще на початку 70-х років минулого століття. Так, український, радянський математик-кібернетик із світовим ім'ям В. Глушков успішно досліджував обчислювальну складність завдання, в той час - планування, процесу більш трудомісткого, ніж регулювання. Ще раніше російсько-американський економіст i Нобелівський лауреат В. Леонтьєв представив виробничий план, як систему лінійних рівнянь матеріального балансу. Інший радянський математик і теж Нобелівський лауреат Л. Канторович досліджував модель об'єктивно обумовленої оцінки, як спосіб математичного виразу кордонів інтервалу суспільно необхідних витрат факторів виробництва в межах потреб при даному технологічному укладі. Нарешті, Нобелівський лауреат $\Phi$. Хайек показав, що значна частина інформації, необхідної для формування матриці коефіцієнтів виробничого балансу, виявляється тільки в самому процесі виробництва, а основна маса відомостей, потрібних для побудови цільової функції пошуку оптимуму, - в процесі споживання. Висновок наведених досліджень Ф. Хайєка в області оптимального планування виробництва полягав у невідворотній неминучості відставання планової економіки від ринкової.

Висновки. Розробка математичних моделей, сучасні можливості циф-ровізації не трансформують економіку автоматично у точну науку, що розк-риває закони господарювання. Цифра важлива, але не вона визначає розви-ток. « Дані заради даних, бездумне нагромадження великих даних без концептуальної основи для їх організації і розуміння може бути заняттям неправильним і навіть небезпечним. Заключення, засновані на одних тільки даних або навіть на математичній апроксимації даних без глибинного розуміння механізмів, які їх породжують, можуть бути оманливими й призводити до помилкових висновків і непередбаченим наслідкам» [7, с. 490]. Своє слово має сказати економічна наука, міждисциплінарні дослідження закономірностей, суперечностей розвитку фрактальних структур та інституцій інформаційного суспільства, базису цифровізації всього господарського життя.

Поряд 3 державним регулюванням вітчизняної економіки, вирішення завдань з їі цифровізації має бути, в першу чергу, нерозривно пов'язано із зростанням морально-етичного, культурного, освітнього рівнів українського суспільства. Цифровізація і глобалізація економіки не повинна перетворюватися в інструментарій поневолення та експлуатації людей, завдавати шкоди соціуму, навпаки, вони повинні справедливо сприяти розподілу результатів спільної господарської діяльності. Морально-етичні, цінності повинні завжди превалювати, саме етика коригує економіки і ринки, оскільки вона знижує суттєво трансакційні витрати, пов'язані з санкціями і контролем. Суспільству варто стежити за тим, щоб приватні ринкові інтереси, в т.ч. й фінансово-промислових груп, не нав'язували всьому загалу свої морально-етичні принципи і «цінності». Важливо змусити ринки через регуляторний вплив держави й використовуючи цифрові технології, працювати на соціум. Значення таких морально-етичних категорій, нематеріальних активів як справедливість, чесність, добра воля, довіра зростають в процесі людської взаємодії в економіці і відіграють чималу роль в готовності або неготовності до співпраці.

3 огляду на зазначене, державне регулювання процесів становлення та розвитку цифрової економіки в Україні має зосередитись на реалізації наступних основних функцій: створення інституціональної інфраструктури діджиталізації економіки і суспільства; сприяння розвитку інформаційних технологій, розбудові вітчизняної мікроелементної бази; перехід від електронного до цифрового врядування; стимулювання цифровізації виробничих процесів і застосування відповідних бізнес-моделей; інформаційна, цифрова безпека; подолання цифрової нерівності і забезпечення рівного доступу до цифрових послуг; боротьба $з$ корупцією через цифровізацію економіки, широке застосування блокчейн-технологій; всезагальна і неперервна цифрова освіта, підготовка фахівців в галузі цифрових технологій, діджиталізації економіки і врядування.

Підсумовуючи, слід зауважити, що не варто вбачити у процесі цифро-візації виробництва товарів і послуг лише технологічні переваги - нову індустріалізацію на цифровій основі, підвищення конкурентоспроможності господарюючих суб'єктів і т.п. У цьому процесі очевидні проблеми й негативні соціальні наслідки, які необхідно враховувати і мінімізувати при реалізації Концепції і стратегії подальшого розвитку цифрової економіки України у наступному десятилітті, не захоплюючись односторонніми технократичними підходами. При всій важливості цифровізації національного господарства варто не забувати, що головний вектор його розвитку - все-таки, соціалізація економіки, виконання нею, насамперед, соціальних функцій із забезпечення добробуту домашніх господарств і суспільства в цілому, сьогодні вже через ефективне застосування цифрових, інформаційних технологій. 


\section{Список літератури:}

1. Белл Д. Грядущее постиндустриальное общество. Опыт социального прогнозирования / Перевод с английского. Изд. 2-ое, испр. и доп. Москва.: Academia, 2004. 788 с.

2. Денисон Э. Ф. Исследование различий в темпах экономического роста. Масква.: Прогресс, 1971. 646 с.

3. Кастельс М. Информационная эпоха. Экономика, общество и культура / Пер. с англ. под науч. ред. О.И. Шкаратана. Москва: ГУ ВШЭ, 2000. 608 с.

4. Machlup F. The Production and Distribution of Knowledge in the United States. - Princeton N.J.: Princeton University Press, $1962.416 \mathrm{p}$.

5. Drucker P.F. Post-Capitalist Society. - Oxford : Butterworth-Heinemann, 1995. 204 p.

6. Вишневський О. С. Цифрові платформи як ядро цифровізації економіки // Цифрова економіка: зб. мат. Національної наук.-метод. конф., 4-5 жовтня 2018 р. м. Київ: КНЕУ, 2018. 407 с.

7. Уэст Дж. Масштаб: Универсальные законы роста, инноваций, устой-чивости и темпов жизни организмов, городов, экономических систем и компаний/ пер. с англ. Д.А. Прокофьева. Москва: Азбука Бизнес, Азбука Аттикус, 2018. 512 с.

8. Букреев В.В. Является ли цифровизация панацеей для российской экономики // Вопросы политической экономии. Вып. 4/2018. Москва: Культурная революция, 2018. 188 с.

9. Кульков В.М. Противоречия развития цифровой экономики // Философия хозяйства. Альманах Центра общественных наук и экономического факультета МГУ им. М.В. Ломоносова. Москва: Специальный выпуск, 2017. $468 \mathrm{c}$.

10.Цифровизация экономики // БИТ. Бизнес \& Информационные технологии. Москва : Издат. дом «Положевец и партнеры». 2018. Вып. № 1 (74). URL: http://bit.samag.ru/uart/more/67 (дата звернення: 03.05.2019).

11. «Цифрові рішення - пріоритет розвитку України» - Зеленський у Парижі відвідав стартап-інкубатор. Київ: TCH, 17 червня 2019. URL: https://tsn.ua/politika/cifrovi-rishennya-prioritet-rozvytku-ukrayini-zelenskiy-u-parizhividvidav-startap-inkubator-1363779.html (дата звернення: 20.06.2019).

12. Розпорядження Кабінету Міністрів України «Про схвалення Концепції розвитку цифрової економіки та суспільства України на 2018-2020 роки та затвердження плану заходів щодо ії реалізації» від 17 січня 2018 р. № 67-р. Київ: Урядовий портал, 17 січня 2019. URL: https://www.kmu.gov.ua/ua/npas/pro-shvalennya-koncepciyi-rozvitkucifrovoyi-ekonomiki-ta-suspilstva-ukrayini-na-20182020-roki-ta-zatverdzhennya-planu-zahodiv-shodo-yiyi-realizaciyi (дата звернення: 15.06.2019).

13.Колодко Г.В. Куда идет мир. Политическая экономия будущего. - Москва: Магистр, 2014. 528 с.

\section{References:}

1. Bell D.(2004). Grjaduschee postindustrialnoe obschestwo. Opyt sozi-alnogo prognozirovania [The Coming of PostIndustrial Society: A Venture in Social Forecasting]. Moscow : Academia, $788 \mathrm{p}$.

2. Denison E.F. (1971). Issledovania razlichij $\mathrm{v}$ tempah economicheskogo rosta [Why growth rates differ; postwar experience in nine western countries]. Moscow : Progress, $646 \mathrm{p}$.

3. Castells M.(2000). Informazionnaja epoha. Ekonomika, obschestvo, kultura [The Information Age: Economy, Society and Culture]. Moscow : Higher School of Economics -National Research University, 608 p.

4. Machlup F. (1962). The Production and Distribution of Knowledge in the United States. Princeton N.J.: Princeton University Press, $416 \mathrm{p}$.

5. Drucker P.F. (1995). Post-Capitalist Society. Oxford : Butterworth-Heinemann, 204 p. and others.

6. Vyshnevskyj O.S. (2018). Zyfrovi platformy jak jadro zyfrovisazii ekonomiky [Digital platforms as the nucleus of digitization of the economy]. Zyfrova ekonomika. Kyiv: KNEU, $407 \mathrm{p}$.

7. West J. (2018). Masshtab: Universalnye zakony rosta, innovazij, ustojchivosti i tempov zisni organismov, gorodov, ekonomicheskih system i kompanij [Scale: The Universal Laws of Growth, Innovation, Sustainability, and the Pace of Life in Organisms, Cities, Economies and Companies]. Moscow:Azbuka Business, Azbuka Atticus, 512 p.

8. Bukreev V.V. (2018). Javlaetsa li zyfrovisazia panazeej dla rossijskoj ekonomiki [Is digitalization a panacea for the Russian economy]. Voprosy politicheskoj ekonomii. Vyp.4. Moscow: Kulturnaja revoluzija, 188 p.

9. Kulkov V.M. (2017). Protivorechia razvitia zyfrovoj ekonomiki. Filosofia hozaystva [Contradictions in the development of the digital economy. Philosophy of Economy]. Moscow: Center for Social Sciences, Moscow State Lomonosov- University, $468 \mathrm{p}$.

10. Zyfrovizatia ekonomiki. Business and Information technology (2018). [Digitalization of the economy. Business \& Information Technology]. Moscow: Polojevec and partners. Available at: http://bit.samag.ru/uart/more/67 (accessed 03.05.2019).

11. «Zyfrovi rishenna - priorytet rosvytku Ukrainy» - Zelensky u Parygi vidvidav startap-inkubator (2019). ["Digital solutions are a priority of Ukraine's development" - Zelensky visits startup incubator in Paris]. Kyiv: TSN. Available at: https://tsn.ua/politika/cifrovi-rishennya-prioritet-rozvitku-ukrayini-zelenskiy-u-parizhi-vidvidav-startap-inkubator-1363779. html (accessed 20.06.2019).

12. Rosporjadgennia Kabinetu Ministriv Ukrainy «Pro shvalennia Konzepzii rosvytku zyfrovoi ekonomiky ta suspilstva Ukrainy na 2018-2020 roky ta zatverdgennia planu zahodiv schodo jii realizazii» (2018). [Ordinance of the Cabinet of Ministers of Ukraine «On approval of the Concept Development of the digital economy and society of Ukraine for 2018-2020 
years and approved plan for its implementation»]. Kyiv: Urjadovy portal. Available at: https://www.kmu.gov.ua/ua/npas/proshvalennya-koncepciyi-rozvitku-cifrovoyi-ekonomiki-ta-suspilstva-ukrayini-na-20182020-roki-ta-zatverdzhennya-planuzahodiv-shodo-yiyi-realizaciyi (accessed 15.06.2019).

13. Kolodko G.V. (2014).Kuda idet mir. Politicheskaja ekonomia buduschego [Whither the world: The political economy of the future]. Moscow: Magister, $528 \mathrm{p}$.

\section{ИНСТИТУЦИОНАЛЬНЫЕ АСПЕКТЫ РАЗВИТИЯ ЦЫФРОВОЙ ЭКОНОМИКИ В УКРАИНЕ}

В статье рассматриваются актуальные проблемы, противоречия стано-вления и развития цифровой экономики в Украине, исследуются особенности и пути их решения в процессе институционально-структурной трансформации экономической системы. Целью статьи является переосмысление отмеченных процессов ијирровизаици экономики и капитала с учетом проблем, вызовов, возможностей и особенностей их реализации в контексте становления и институционализации информационного общества в Украине. Проанализировань институцчиональные аспекты реализации Концепции развития цифровой экономики и общества Украинь на 2018-2020 годь, раскрыта роль и основные функции государственного регулирования ицифровизации эконо-мики эмерджентного типа, в частности, создание институциональной инфра-структуры диджттализации экономики и общества, переход от электронного к ицирровому управлению. стимулирование циифровизации производственных процессов, информационная, цифрровая безопасность и преодоление иифррового неравенства.

Ключевые слова: интернет, институциональные трансформаџии, ин-формаџионное общество, информационные технологии, ІТ-индустрия, цииф-ровизация, цчифровое управление, цчифровая экономика.

\section{INSTITUTIONAL ASPECTS OF THE DEVELOPMENT OF DIGITAL ECONOMY IN UKRAINE}

The article discusses actual problems, contradictions of the formation and development of the digital economy in Ukraine, explores the features and ways to solve them in the process of institutional and structural transformation of the eco-nomic system. The purpose of the article is to rethinking these processes of digitalization of the economy and capital in view of the problems, challenges, possibilities and peculiarities of their implementation in the context of the formation and institutionalization of the information society in Ukraine. It is noted that the important role of digitization as a way to modernize the Ukrainian economy does not exclude its main problems : underestimation of social and other dimensions of the modern economy development, for example, heterogeneity of Ukrainian regions development; reduced productivity in the production of digital technology itself, and, in turn, the slowdown of investment in their development; reduction of production personnel qualifications in conditions of its transformation in the appendage of digitalized productions; growth of probability of technological failures and man-made disasters, information-digital manipulations and fraudulent operations in the non-productive sector; deceleration in the growth of the share of the digital economy in GDP already is observed in a number of industrialized countries; elimination of basic technological processes, scientific and technical innovations, as well as economic relations related to the social orientation of the Ukrainian economy; limited possibilities for taking into account the specifics of the Ukrainian economy, the correlation of state regulation and the market; threats to the country's economic security, first of all, to its cyber and military-industrial safety; exit of domestic IT-companies from the state control, taxation, etc. As a result of the institutional analysis of implementation of the Concept of development of the digital economy and society of Ukraine for 2018-2020 years revealed the role and the basic functions of state regulation of digitalization emergent type of economy, in particular, the creation of the institutional infrastructure of the economy and society digitalization, the transition from e-government to digital governance, promotion of production processes digitalization, information, digital security and overcoming of the digital inequality. The practical significance of the research is that the conclusions and proposals can be used in refining and further refining the strategy of digital transformation of the Ukrainian economy and its successful integration into the global digital space.

Key words: digitalization, digital governance, digital economy, information technologies, information society, internet, IT-industry, institutional transformations. 